Trakya Üniversitesi

Eğitim Fakültesi Dergisi

XV. Uluslararası Katılımlı Sınıf Öğretmenliği

Eğitimi Sempozyumu (11-14 Mayıs 2016)

USOS 2016 Özel Sayısı, 136-161

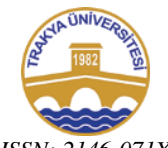

ISSN: 2146-071X
Trakya University

Journal of Education Faculty

XV. International Primary Teacher Education

Symposium (11-14 May 2016)

IPTES 2016 Special Issue, 136-161

Doi:10.24315/trkefd.366700

Gelis Tarihi: 28.11 .2016

Yayına Kabul Tarihi: 27.07.2017

\title{
Yapılandırmacı Öğrenme Yaklaşımına Göre Çocuğu Merkeze Almak ve İlgilenmek ${ }^{1}$
}

\section{Child Centered and Care based Practices According to Constructivist Learning Approach}

\author{
Ayşe Nur KUTLUCA CANBULAT ${ }^{2}$, Süleyman YÜCE
}

Öz: Yapılandırmacı öğrenme yaklaşımına göre öğrenme, bireyin yapılandırma sürecini etkileyen içsel ve dişsal faktörlerin uyumu ile açıklanabilir. Bu çalışmanın amacı, çocuğu tanıyarak geliştirmeye yönelik çabalar olarak açıklanabilecek olan "çocukla ilgilenmenin" öğretmen, veli ve çocuk için ne anlama geldiğini belirlemeye çalışmaktır. Araştırma betimsel bir çalışma niteliğinde olup araştırma verileri 2015-2016 öğretim y1lında Antalya ilinde kolay ulaşılabilir örnekleme yoluyla belirlenmiş 150 kişiden yarı-yapılandırılmış görüşme soruları aracılığıyla toplanmıştır. Araştırma verileri, betimsel içerik analizi ile analiz edilmiştir. Araştırma bulguları incelendiğinde, öğretmen ve veli açısından çocukla ilgilenmenin çocuğu akademik başarıya ulaştırma için bilgi öğretmekle ilişkilendirildiğgi, özellikle aileler açısından ise çocukların istek ve ihtiyaçlarının karşılanması olarak algılandığı görülmüş̧tür. Çocukların ise öğretmenlerinin kendileriyle ilgilenmesini öğretme kavramıyla, anne baba ilgisini ise daha çok istek ve ihtiyaçlarını karşılamaları ile açıkladıkları görülmüştür. Araştırma sonucunda, çalışma grubunun, çocukla ilgilenme kavramını yapılandırmacı öğrenme ortamları ile ilişkilendiremedikleri, hala davranışçı öğrenme yaklaşımına göre beklentilerinin şekillendiği ve öğrenme-öğretme sürecine yön verdikleri söylenebilir.

Anahtar sözcükler: Çocukla ilgilenmek, yapılandırmacı öğrenme yaklaşımı, yapılandırmacı öğrenme ortamları.

Abstract: Learning can be explained by the harmony between internal and external factors that affect the construction process of individuals. This study aimed to identify what "taking care of the child" means for teachers, parents and children. The descriptive study was conducted in 2015-2016 academic year and data were collected from a total of 150 individuals identified. Research data were analyzed by using descriptive content analysis. Research findings show that taking care of the child was

1 Bu çalışma 11-14 Mayıs 2016 tarihinde Muğla Sttkı Koçman Üniversitesi tarafindan düzenlenen XV. Uluslararası Sınıf Öğretmenliği Eğitimi Sempozyumu'nda sözlü bildiri olarak sunulmuştur.

2Yrd. Doç. Dr., Akdeniz Üniversitesi, aysenur.canbulat@gmail.com

3Öğretmen, MEB, slmnyc@gmail.com 
associated by teachers and parents with providing information in order to have children acquire academic achievement; parents were perceived as meeting the requests and needs while children explain teacher interest and care with the concept of teaching and they explain parental care and interest as being shown that they are loved and having their requests and needs met. It can be claimed that research results point to a lack of constructivist learning environments in which these roles are supposed to be displayed in terms of taking care of children and learning-teaching process is still guided by behavioral learning approach.

Keywords: Taking care of the child, constructivist learning approach, constructivist learning environments.

\section{GíRíş}

Geçmişten günümüze öğrenenin nasıl öğrendiği sorusu farklı açılardan açıklanmaya çalışılmıştır. Öğrenmenin bireysel bir süreç olduğu düşüncesi kabul gördükçe öğrencinin sadece bir "kayıt cihazı” gibi görüldüğü öğretmen merkezli yaklaşımlar yerini, öğrenme ortamlarının öğrencinin ihtiyaç ve ilgisine göre hazırlandığı, öğretmenin ise bir rehber olarak görüldüğü öğrenen merkezli yaklaşımlara bırakmıştır. Öğrenen merkezli yaklaşımlar öğretim programlarını öğrenciye göre düzenleyerek öğrenme işini bireyselleştirme yoluyla çocuğu merkeze alır (Güneş, 2014; Arslan ve Özpınar, 2008). Son yıllarda Amerika Birleşik Devletleri, Avustralya, İspanya, İngiltere, İsrail, Kanada gibi pek çok ülkenin eğitim sistemini derinden etkileyen ve günümüz eğitim sistemlerine egemen olan öğrenci merkezli anlayış getiren yaklaşımlardan biri de, öğrenenin geçmiş bilgileri ile yeni bilgisi arasında bağ kurarak anlamı yapılandırması üzerine odaklanan yapılandırmacı öğrenme yaklaşımıdır (Henson, 2003). Yapılandırmacı öğrenme yaklaşımına göre öğrenme sürecinde çocuk ön bilgi ve yaşantılarını kullanarak, yeni bilgilerle önceki bilgileri arasında bağ kurarak bilgiyi zihninde yapılandırır. Bu bağ ise öğrencilerin gelişim özellikleri, zekâ düzeyleri ve alanları, öğrenme biçimleri, yaratıcılıkları, tutumları ve güdülenmişlik düzeyleri, kişilik özellikleri, ilgi, ihtiyaç, beceri ve alışkanlıkları gibi birçok özelliğin etkisi ile kurulabilmektedir. Bu nedenle yapılandırmacı yaklaşım; öğrencilerin; bireysel ihtiyaçlarına, güçlü ve zayıf yönlerine, ilgilerine ve deneyimlerine önem vermektedir (Çiftci, Sünbül ve Köksal,2013). Piaget ve Bruner'in fikirlerinin öncülüğünde ilerleyen bilişsel yapılandırmacılık ve Glasersfeld'in geliştirdiği radikal yapılandırmacılık, öğrenme sürecini açıklarken günlük yaşamdaki bireysel deneyimler ve bu deneyimlerden ne anlaşıldığına odaklanır. Vygotsky'nin görüşlerini temel alan sosyal yapılandırmacılık ise kültürel ve sosyal olarak düzenlenmiş etkinliklerle bilgiyi yapılandırma arasında bağlantı kurmayı esas alır (Fer, 2009). Sosyal yapılandırmacılık anlayışına göre birey yalnız ve çevreden bağımsız değildir. Öğrenme süreci her ne kadar bireyin bilgi ve beceri birikimini kullanarak aktif olarak kendisinin yönettiği bir yapılandırma süreci olsa da bireyin bilgi ve becerilerinin yeterliliği ve kalitesini etkileyen çevresel faktörler de vardır. Birey içine doğduğu çevrenin kendisine sunulan öğrenme olanaklarına bağlı olarak yapılandırma sürecinde rol alır. Dolayısıyla öğrencinin öğrenmesini yapılandırma süreci kendisine rehberlik yapabilecek ve yönlendirecek desteklere ihtiyaç duyduğu bir süreçtir. Sosyal bağlamda anlam yapılandırılırken de bireyler; 
oluşturdukları anlamı paylaşarak diğer bireylerin düşünüşlerini etkiler, kendileri de bu bireylerden etkilenir (Fer\&Cırık, 2007). Çünkü öğrenme aynı zamanda toplumsaldır ve bağlamsal olarak anlam kurma sürecidir (Arslan, 2010). Yapılandırmacılık öğrenmeyi, öğrencilerin çevreleriyle etkileşimi sonucu ortaya çıkan yorumlayıcı ve doğrusal olmayan bir inşa süreci olarak tanımlar (Ocak,2012). Bu süreçte oluşturulan öğrenme ortamları önemli görülmektedir. Yapılandırmacı öğrenme ortamında öğrenenin ne öğreneceğinden çok, neden ve nasıl öğreneceği önemli görülmektedir (Erdem ve Demirel, 2002). Öğrencinin öğrenme açısından başarıyı yakalaması öncelikle çocuğun kendisi kadar ailesi ve yakın çevresi ve öğretmenin bu yapılandırma süreci için ne kadar çaba sarf ettiği ile ilişkilidir.

Türkiye'de 2005-2006 öğretim yılından itibaren yapılandırmacı eğitim uygulanmaya başlanmıştır. Ancak eğitim sistemlerinde yapılan değişiklikler sürecin bir başlangıcıdır ve programı uygulayanlar öğretmenlerdir. Çağın ihtiyaç duyduğu eleştiren, sorgulayan, üretken ve yenilikçi bireyler yetiştirilebilmesi için öğretmenlere büyük görev düşmektedir (Özenç ve Doğan,2007). Yapılandırmacı yaklaşımla birlikte öğretmenlerin,öğrencilerin ve hatta ailelerin rollerinde de bir takım değişiklikler meydana gelmiştir. Yapılandırmacı yaklaşıma göre sınıf ortamı bilginin beslendiği ve büyütüldüğü yerdir (Brumbaugh ve Rock, 2006'den akt: Aygören, 2009). Öğrenme deneyimleri yaşanan, planların esnek olduğu, öğrencilerin bilgilerini yapılandırması için uygun bir ortamı ifade eden yapılandırmacı öğrenme ortamında öğretmenin etkili rehberliği öğrenme ortamlarının öğrenci merkezli olmasına rağmen oldukça önemli görülmektedir. Çünkü yapılandırmacı öğrenme ortamları ile birlikte öğrencilerin ilgi, ihtiyaç ve beklentilerini dikkate alan, etkin katılımına dayalı, üst düzey düşünme becerilerinin desteklendiği, deneyimler kazandıracak etkinlikler barındıran, sosyal etkileşimin ve iletişimin önemsendiği bir süreç yaşanmaktadır (Aygören,2009). Eğitim-öğretimin kalitesi ve etkililiği öğretmenin niteliğiyle doğrudan ilişkili olduğundan (Karaçalı, 2004), öğretim programı çok iyi hazırlanmış olsa bile, öğretmenler istenilen yeterliklere sahip değillerse eğitim-öğretimde istenen sonuçlara ulaşılamaz (Yaşar, Gültekin, Türkan, Yıldız ve Girmen, 2005; Demirel ve Kaya, 2006). Dolayısıyla yeni gelişmelerle ortaya çıkan niteliklerin ancak öğretmenler tarafından etkin bir biçimde uygulamaya dönüştürülmesi ile sağlanacağı açıktır (Dündar, 2008). Öğrencinin aktif katılımına bağlı bu süreçte öğretmen, öğrenme birimine uygun etkileşimli ve canlı bir öğrenme ortamı oluşturur (Ocak,2012) ve bilgiyi doğrudan aktarmak yerine öğrencinin önceki bilgileri ile yeni kazandıkları bilgiler arasında bağlantı kurmasına yardımcı olur (Copley,1992).Öğretmen bu rolüyle öğrencilerin gelişim özelliklerini ve bireysel farklılıklarını dikkate alarak öğrencilerini öğrenmeye cesaretlendiren (Akyol,2007), düşündüren, tartıştıran, dinleyen, yönlendiren, motive eden aynı zamanda açık fikirli, çağdaş, kendini yenileyebilen ve öğrenenle birlikte öğrenen, (Demirel, 2008) sade, anlaşılır ve akıcı bir dil ve etkileşimli öğretim materyallerini kullanarak öğrenmeyi kolaylaştıran öğrencilerinin ilk elden bilgi edinmelerine yardımcı olan ve öğrenci gelişimini çoklu değerlendirme yollarıyla değerlendirebilen bir rehberdir (Akpınar ve Ergin, 2005). Bu sürecin en önemli öğesi sayılabilecek öğrenen yani öğrenci ise soru soran, sorgulayan, kendi 
problemlerini kuran ve çözen, düşünen, tartışan, birlikte çalışabilen birey, demokratik bir sınıf ortamında, ihtiyaçlarına uygun öğrenme içeriğgi ile etkileşimde bulunarak bütünün parçalarını yorumlayan parçalardan anlamlı bilgiyi oluşturan birey olarak görülebilir. Öğrenme ortamında öğrenenin ne öğreneceğinden çok neden ve nasıl öğreneceği önemlidir (Erdem ve Demirel, 2002; Ocak,2012; Arslan ve Özpınar,2008). Öğretmenin bu süreci iyi yönlendirebilmesi ve süreçten en üst düzeyde verim elde edebilmesi, yapılandırmacı öğrenme yaklaşımını anlama ve uygulama seviyesi ile doğrudan ilişkili görülmektedir (Metin ve Özmen,2009). Titiz (1999) öğrenmenin öğretmen-öğrenci işbirliğiyle gerçekleştiğini ifade etmektedir. Hatta bu işbirliği sürecine velinin de katılması öğrenme sürecinin tamamlanması açısından önemli görülmektedir. Bireyin ailede başlayan öğretmeöğrenme süreçleri okulda sürer ve aile ile onun çevresindeki etkileşimlerle tamamlanır. Dolayısıyla öğretmen, öğrenci ve hatta veli aynı amaç-çocuğun öğrenmesi-için işbirliği yapması gereken paydaşlar olarak görülebilir. $\mathrm{Bu}$ işbirliğinin gerçekleşebilmesi için ise öğrencinin kendisini tanıması ile birlikte aile ve öğretmenin de ilgi ve ihtiyaçları ile öğrenciyi tanıması gereklidir. Sınıf ve okul ortamında öğrenme etkinliklerinin başarıyla sürdürülmesinde öğretmenler kadar velilerin de etkisi büyüktür (Topçu,2013). Bu nedenle velinin çocuğa ve öğrenmeye yaklaşımı üstlendiği roller önemli görülmektedir.

Okula her çevreden, birbirinden farklı davranış ve alışkanlıklara sahip öğrenciler gelmektedir. Öğretmen ise bu farklılıklarla baş edebilmek ve kaliteli bir eğitim öğretim süreci yürütebilmek için onları çevresiyle birlikte tanımalıdır. Çocuk neleri yapabilir, yaptıklarını ne kadar zamanda ne kadar iyi yapabilir, güç durumlarla karşılaştığında bunları nasıl karşılar ve nasıl çözer gibi özelliklerin bilmesi gerekir. Öğrencilerin özelliklerini, gereksinimlerini sorunlarını ve bilmeden öğrenmesini sağlamak olanaksızdır. Dolayısıyla öğretim etkinlikleri planlanırken öğrenciyi merkeze almalı ve onun bilgi ve ihtiyaçlarından yola çıkılmalıdır. Öğrenci; hazır bulunuşluk düzeyi, fiziksel özellikleri, sosyoekonomik özellikleri, zihinsel özellikleri,duygusal özellikleri, ilgi ve yetenekleri, yetersiz ve eksik yönleri ile çok yönlü olarak tanınmalı ve eğitim öğretim faaliyetleri ögrencinin bu özelliklerine uygun bir şekilde yapılandırılmalıdır. Planlanan ve uygulamaya dönüştürülecek eğitimsel faaliyetlerinin amacına ulaşabilmesi yapılandırmacı yaklaşıma uygun öğrenme ortamları oluşturulmasına bağlıdır. Öğrenme ortamlarının yapılandırmacı öğrenmeye uygunluğu gerçekleştirilmek istenen eğitim-öğretim faaliyetlerinin etkililiği açısından önemli görülmektedir. Ancak yapılandırmacı öğrenme yaklaşımının benimsendiği öğretim programlarına yönelik uygulamaların ne derece yapılandırmac1 olduğunun değerlendirilmesi gerekmektedir, aksi takdirde eğitimsel ve öğretimsel faaliyetlerden istenilen sonuçlar elde edilmediğinde sorun yaklaşımda görülebilmekte yeni arayışlar içine girilebilmektedir. Ancak ülkemizde öğrenme ortamlarının yapılandırmacı yaklaşıma uygunluğuna yönelik olarak henüz yeterli çalışma yoktur (Arkün ve Aşkar,2010).

Öğrencinin öğrenme sürecine aktif katılımını sağlayabilecek öğrenme ortamlarının oluşturulabilmesi için öğretmenin yapması gereken, öğrenci ile eğitim programı arasında aracılık etmek (Açıkgöz, 2003) başka bir deyişle öğrencisini ilgi, ihtiyaç ve yetenekleri ile tanıyarak uygun öğrenme ortamları 
hazırlayarak öğrenme sürecine katkı sağlayabilmektir. Çocuğun öğrenmesi için ilgi ve ihtiyaçları ile tanıyarak öğrenme ortamları hazırlamak ve ögrenmeleri için desteklemek öğretmen ve ailelerin sorumlulukları arasındadır. Çocuk hangi bilgi ve becerilere sahiptir? Birey bilgiyi yapılandıracak ama nasıl? Öğretmen neler yapmalıdır, anne babaya bu süreçtehangi roller düşmektedir?, Çocuk ne beklemektedir?, Bu süreçte çocuğun ilgi ve ihtiyaçları nasıl şekillenmektedir? gibi soruların cevabının bilinmesi gerekir.

İlk öğrenme yaşantılarının ilkokul düzeyinde olduğu düşünüldüğünde sınıf öğretmenlerinin sunacağı yapılandırmacı öğrenme ortamlarına ihtiyaç duyulacağ düşünülmektedir. Öğrenen merkezli bir yaklaşımda bireyin öğrenebilmesine rehberlik yapacak olan öğretmenin öğrenen ile ilgili faktörler(öğrenenin kendisi ve sosyal çevresi), öğrenme malzemesi ve yöntemi ile ilgili faktörler (Seven ve Engin,2008) gibi birçok özellik arasında ilişki kurarak öğrenme ortamını oluşturması ve öğrenciyi öğrenmeye hazır hale getirmesi gereklidir. Ancak böyle bir öğrenme ortamı hazırlandığında ilgilenme kavramından söz edilebilir. Bir öğretim programının etkililiği ve öğrenme ortamının öğrenen merkezli olarak yapılandırılması için çocukla gerçek anlamda ilgilenmek önemli görülmektedir. $\mathrm{Bu}$ süreçte aileye de önemli görevler düşmektedir. Aile de çocuğun eğitimsel anlamda desteklenmesi için çocuklarıyla ilgilenmelidir. Ancak ailenin çocuğun gelişimi ve eğitimsel olarak nasıl destekleyeceklerini bilmeleri önemli görülmektedir.

\subsection{Amaç}

$\mathrm{Bu}$ çalışmada çocuğun bilişsel (öğrenme ihtiyaçları), dilsel, fiziksel, duygusal ve sosyal ihtiyaçları, ilgileri, becerileri ile çocuğu tanıyarak geliştirmeye yönelik çabalar olarak açıklanabilecek olan "çocuğu merkeze almak ve çocukla ilgilenme "nin öğretmen, veli ve öğrenci açısından ne ifade ettiği araştırılmak istenmiştir. Bu amaç doğrultusunda aşağıdaki sorulara cevap aranmıştır.

Öğrenen merkezli eğitim anlayışı ile Yapılandırmacı öğrenme yaklaşımının yeni roller tanımladığı;

- $\quad$ Öğretmenler için “eğitimsel anlamda çocuğu merkeze almak ve çocukla ilgilenmek" ne anlam ifade etmektedir?

- Veliler için "eğitimsel anlamda çocuğu merkeze almak çocukla ilgilenmek" ne anlam ifade etmektedir?

- Çocuklar için "eğitimsel anlamda öğretmen ve velisinin kendileriyle ilgilenmesi” ne anlam ifade etmektedir?

\section{YÖNTEM}

Araştırma betimsel bir çalışma niteliğinde olup araştırma verileri nitel araştırma yönteminde sıklıkla kullanılan görüşme tekniği ile toplanmıştır. Görüşme tekniğinin kullanılmasının nedeni öğretmenlerin, velilerin ve çocukların "ilgilenmek" ifadesinden eğitimsel anlamda ne anladığını derinlemesine çalışabilmektir. Araştırma verileri yarı yapılandırılmış görüşme soruları aracılığı ile toplanmıştır. 


\section{1. Çalışma Grubu}

Araştırma 2015-2016 eğitim-öğretim y1lı bahar yarıyılında gerçekleştirilmiş olup araştırmanın çalışma grubu Antalya merkez ilkokullarında görev yapan ve araştırmaya katılmaya gönüllü olan 504 . sınıf öğretmeni, bu öğretmenlerin 50 öğrencisi ve bu öğrencilerinvelileri (50) olmak üzere 150 kişi ile gerçekleştirilmiştir İlgili veriler sunulurken katılımcı ifadeleri öğretmenler Ö1.....50, öğrenciler, Ç1.....Ç50; veliler için ise V1.....V50 şeklinde kodlanarak sunulmuştur.

Tablo 1: Çalışma grubuna ilişkin bilgiler

\begin{tabular}{|c|c|c|c|c|}
\hline $\begin{array}{c}\text { Öğretmen } \\
\mathrm{f}\end{array}$ & Cinsiyet & $\begin{array}{c}\text { Mesleki } \\
\text { deneyim }\end{array}$ & $\begin{array}{c}\text { Okuttuğu Sinıf } \\
\text { seviyesi }\end{array}$ & Mezuniyet \\
\hline 50 & $\begin{array}{l}\text { 34Bayan } \\
\text { 16Erkek }\end{array}$ & $\begin{array}{l}27 \text { öğretmen- } \\
15-20 \text { y1l } \\
11 \text { ögretmen- } \\
10-15 \text { y1l } \\
8 \text { öğretmen- } \\
21 \text { y1l+ } \\
4 \text { öğretmen-1- } \\
10 \text { y1l }\end{array}$ & 4.Sinif & $\begin{array}{l}38 \text { öğretmen-Sınıf } \\
\text { öğretmenliği } \\
8 \text { öğretmen-Ön } \\
\text { lisans } \\
2 \text { öğretmen-Branş } \\
\text { öğretmenliği } \\
\text { 2öğretmen-Alan } \\
\text { mezunu }\end{array}$ \\
\hline $\begin{array}{c}\text { Veli } \\
\mathrm{f} \\
\end{array}$ & Cinsiyet & Mesleği & Aylık geliri & Eğitim Düzeyi \\
\hline 50 & $\begin{array}{c}27 \\
\text { Bayan } \\
23 \\
\text { Erkek }\end{array}$ & $\begin{array}{l}18 \text { ev hanımı } \\
13 \text { çiftçi } \\
8 \text { işçi } \\
5 \text { işletme sahibi } \\
6 \text { memur }\end{array}$ & $\begin{array}{l}10 \text { veli-1000- } \\
2000 \text { TL } \\
29 \text { veli-2000- } \\
3500 \mathrm{TL} \\
11 \text { veli-3500 } \\
\text { TL + }\end{array}$ & $\begin{array}{l}22 \text { veli-ortaokul } \\
\text { mezunu } \\
10 \text { veli-lise mezunu } \\
9 \text { veli-ilkokul } \\
\text { mezunu } \\
7 \text { veli-ön lisans } \\
\text { mezunu } \\
2 \text { veli-lisans mezunu }\end{array}$ \\
\hline $\begin{array}{c}\text { Öğrenci } \\
\mathrm{f}\end{array}$ & \multicolumn{2}{|r|}{ Cinsiyet } & \multicolumn{2}{|c|}{ Sinıf seviyesi } \\
\hline 50 & \multicolumn{2}{|r|}{$\begin{array}{c}27 \mathrm{kuz} \\
23 \text { erkek }\end{array}$} & \multicolumn{2}{|r|}{4} \\
\hline
\end{tabular}

\subsection{Verilerin Analizi}

Araştırma verileri, verilerin daha önceden belirlenmiş temalara göre özetlenmesi ve yorumlanmasını içeren betimsel analiz tekniği ile analiz edilmiştir. $\mathrm{Bu}$ analiz türünde araştırmacı görüştüğü ya da gözlemiş olduğu bireylerin görüşlerini çarpıcı bir biçimde yansıtabilmek ve elde edilmiş olan bulguların okuyucuya özetlenmiş ve yorumlanmış bir biçimde sunmak amacıyla doğrudan alıntılara sık sık yer verebilmektedir (Yıldırım ve Şimşek, 2005). Bu çalışmada da öğretmenlerin hem kendileri hem de veliler açısından çocuğu merkeze alarak ilgilenmesi, velilerin hem öğretmenlerinin hem de kendilerinin veli olarak çocuğuyla ilgilenmesi, çocukların da veli ve öğretmenlerinin kendileriyle ilgilenmesine yönelik kategoriler oluşturulmuş ve ilgili veriler sık sık alıntılarla da desteklenereksunulmuştur. 


\section{BULGULAR}

Araştırma bulgularında çocukla ilgilenmek kavramı ile ilgili olarak öğretmen, veli ve çocuğun görüşlerine yer verilmiştir.

\subsection{Birinci alt probleme ilişkin bulgular}

Birinci alt problemle ilgili olarak öğretmenlerin öğretmen olarak kendilerinin çocukla ilgilenmesi ve velinin çocuğuyla ilgilenmesine yükledikleri anlamlar bağlamında vermiş oldukları cevaplara ilişkin bulgular Tablo 2'de verilmiştir.

Tablo 2.Öğretmenlerin çocukla ilgilenmeye yönelik görüşleri

\begin{tabular}{|c|c|c|c|}
\hline Öğretmenin çocukla ilgilenmesi & f & Velisinin çocuğuyla ilgilenmesi & $\mathbf{f}$ \\
\hline $\begin{array}{l}\text { Başarı odaklı çalışma (sınavlarda } \\
\text { başarı yakalama) }\end{array}$ & 38 & $\begin{array}{l}\text { Sevgi ihtiyacını karşılama (sevdiğini } \\
\text { gösterme, söyleme) }\end{array}$ & 42 \\
\hline Bilgi öğretme & 38 & Öğretmen ile işbirliği ve iletișim & 31 \\
\hline $\begin{array}{l}\text { Öğrenci ile iyiiletişim kurma } \\
\text { (empati kurma, değer verme, eşit ve } \\
\text { adaletli davranma, dinleme, } \\
\text { kiyaslamama, yargılamama, } \\
\text { cesaretlendirme, güven verme, güler } \\
\text { yüzlü olma) }\end{array}$ & 24 & $\begin{array}{l}\text { Çocuğuyla iyi iletişim kurma (anlama, } \\
\text { dinleme, baskı yapmama, güvenme, } \\
\text { kıyaslamama, tutarlı olma) }\end{array}$ & 28 \\
\hline $\begin{array}{l}\text { Veli ile iyi iletişim kurma } \\
\text { (empatikurma, saygı duyma ve güler } \\
\text { yüzlü davranma) }\end{array}$ & 21 & Ödevlerine yardım etme & 27 \\
\hline Ahlaki değerlerkazandırma & 21 & $\begin{array}{l}\text { Başarısını takdir etme (aferin, daha iyisini } \\
\text { yapabilirsin vb.) }\end{array}$ & 25 \\
\hline Müfredata uygun eğitim & 19 & $\begin{array}{l}\text { Ögrencinin temizlik, tertip ve düzeni ile } \\
\text { ilgilenme }\end{array}$ & 23 \\
\hline Sorunları ile ilgilenme & 13 & Ahlaki değerler kazandırma & 21 \\
\hline $\begin{array}{l}\text { Öğrenciyi tanıma (ailesi, ev ortamı, } \\
\text { eksiklik ve yetersizlikleri ile) }\end{array}$ & 8 & $\begin{array}{l}\text { Öğrenme ortamı hazırlama ( ayrı oda } \\
\text { verme, tv kapatma, başka şeylerle meşgul } \\
\text { olmama) }\end{array}$ & 18 \\
\hline $\begin{array}{l}\text { Sosyal aktiviteler düzenleme } \\
\text { (sinemaya, tiyatroya götürme) }\end{array}$ & 8 & $\begin{array}{l}\text { Birlikte nitelikli zaman geçirme (oyun } \\
\text { oynama, aktivite yapma) }\end{array}$ & 12 \\
\hline $\begin{array}{l}\text { Özbakımlarına yönelik çalışmalar } \\
\text { yapma }\end{array}$ & 7 & $\begin{array}{l}\text { Okul araç gereçlerinin tam ve düzenli } \\
\text { olduğunu takip etme }\end{array}$ & 11 \\
\hline $\begin{array}{l}\text { Sağlıklı beslenme alışkanlığı } \\
\text { kazandırma }\end{array}$ & 6 & Derslerle ilgili sorular sorma & 10 \\
\hline $\begin{array}{l}\text { Bilgi yüklemek yerinerehberlik } \\
\text { yapma }\end{array}$ & 5 & Günlük çalışma planı hazırlama & 9 \\
\hline Seviyesine uygun eğitim verme & 4 & $\begin{array}{l}\text { Beslenme ihtiyacını karşılama (okula aç } \\
\text { göndermeme, beslenme hazırlama) }\end{array}$ & 6 \\
\hline $\begin{array}{l}\text { Birlikte etkinlik yapma (öğretmen } \\
\text { katılımlı oyun) }\end{array}$ & 4 & Sağlık takibi ve kontrolü & 5 \\
\hline \multirow[t]{4}{*}{ Eksiklerini giderme } & 2 & $\begin{array}{l}\text { İstediğini almak-yapmak-para vermek } \\
\text { değil }\end{array}$ & 4 \\
\hline & & Becerisine göre yönlendirme & 3 \\
\hline & & Öğrenme etkinliklerine katılım & 2 \\
\hline & & Örnek olma (kitap okuma) & 2 \\
\hline
\end{tabular}

Bir öğretmenin sınıfındaki bir çocukla eğitimsel anlamda ilgilenmesi öğretmen görev ve sorumlulukları ile ilişkili bir durumdur. Tablo 2 incelendiğinde öğretmenlerin çocukla ilgilenmenin öğretmen açısından ne anlama geldiğine ilişkin sorulan soruya en çok "başarı odaklı çalışmak ve bilgi öğretme" ile ilişkilendirerek cevap verdikleri anlaşılmaktadır. Öğretmenlerin yarıya yakını 
ilgilenmek kavramını veli ile iyi iletişim kurma, çocukla iyi bir iletişim kurma,ahlaki değer kazandırma olarak açıklamışlardır. İlgilenme kavramını müfredata uygun eğitim verme ile açıklayan öğretmenler de bulunmaktadır. Ancak öğrencilerin sorunları ile ilgilenme, öğrenciyi tanıma, sosyal aktiviteler düzenleme, öz-bakımlarına yönelik çalışmalar yapma, öğrencilere sağlıklı beslenme alışkanlığı kazandırma, öğrenciye bilgi yüklemek yerine rehberlik yapma, seviyesine uygun eğitim verme, öğretmenin de katıldığı etkinlikler düzenleme ve birlikte oyunlar oynama, eksiklerini giderme gibi eğitimsel anlamda çocukla ilgilenmekle ilişkilendirilebilecek ifadeleri kullanan çok az sayıda öğretmen olduğu görülmektedir.

Öğrenci ile ilgilenmenin onun akademik başarısını arttırmak ve bilgi öğretmekle ilişkilendiren Ö12 şu ifadeleri kullanmıştır.

“Öğretmen ögretendir. Velinin öğretemediğini de ögreten. Bilgiyi, beceriyi ögreten. Çocuklarımız geleceğe iyi hazırlanmalıdır. Aileler ilgisizse her şey size kalıyor. Bu nedenle başarılı olmaları için bilgi ve becerilerin öğretilmesi gerekir. Doğruyu yanlışı ögretmek gerekir."

Öğretmenlerin velinin çocuğuyla ilgilenmesini de en çok "sevgi ihtiyacının karşılanması" ile ilişkilendirdikleri daha sonra sırasıyla, çocuğuyla iyi bir iletişim kurma (anlama, dinleme, baskı yapmama, güvenme, kıyaslamama, tutarlı olma vb.), ödevlerine yardım etme, öğrenci başarısını takdir etme, temizliği ve tertibi ile ilgilenme, Ahlaki değerler kazandırma öğrenme ortamı hazırlama (ayrı oda, tv kapatma, başka şeylerle meşgul olmama vb.) birlikte nitelikli zaman geçirme (oyun oynama, aktivite yapma), okul araç gereçlerinin tam ve düzenli olduğunu takip etme çocuğu takip etme-derslerle ilgili sorular sorma, günlük çalışma planı hazırlama beslenme ihtiyacıni karşilama (okula aç göndermeme, okula yiyecek gönderme vb.), sağlık takibi ve kontrolü,para vermek yerine istediğini almayapma gibi ifadeler ilgilenmek kavramının karşılığında verilen cevaplar olarak görülmektedir. $\mathrm{Bu}$ ifadeler incelendiğinde öğretmenlerin çoğunun velilerden yalnızca kendilerinin yönlendirmeleri doğrultusunda eğitim-öğretim faaliyetlerine katılmalarını istedikleri, çocuklarını da maddi ve manevi yönden desteklemelerini bekledikleri; çocuğunu becerisine göre yönlendirme, etkinliklere katılım ve örnek olma (kitap okuma) gibi eğitim faaliyetlerinin içinde olması gibi yok denecek kadar az öğretmen tarafindan ifade edildiği görülmektedir.

Öğretmen ilgisinin ne demek olduğunu açıklayan öğretmenlerden Ö2 düşüncesini şu ifadelerle açıklamaya çalışmıştır.

“Öğretmen gelecekle ilgili çocuklarl yetiştiren, geleceği belirleyen gençlerin yetişmesine önderlik yapan kimsedir. Birinci derecede ögrencinin ĕgitimi, ikinci derece öğretimi bunlarla öğretmen ilgilendiği sürece velisiyle de görüşerek ögrenci başarılı olur”"

İlgilenmek ifadesini öğrenciyi tanımak ve sorunlarıyla ilgilenmek olarak açıklayan Ö1 ise şu ifadeleri kullanmıştır. 
"İlgilenmek deyince aklıma ögrencilerimin her sorunuyla her şeyiyle sırf dersiyle değil, ailedeki durumları ne bileyim, beslenmesi, giyinmesi her şeyiyle ilgilenmek geliyor bana. Sevgi geliyor ilgi deyince sevmek yani. Velilerimizin ögretmenden beklentileri çok yüksek. Şimdi eğitim seviyelerinin düşük olmasından dolayı, çok çalışıyor olmalarında dolayı çocuklarına zaman ayırmıyorlar. Tamamen yani bize birakmış vaziyetteler.

İlgilenmek ifadesini öğretmen görev ve sorumlulukları ile açıklamaya çalışan ve öğretmenliğin yalnızca bilgi öğretmek olmadığını açıklayan çok az sayıda öğretmenden Ö11 öğretmenin sınıfındaki bir çocukla ilgilenmenin ne anlama geldiğini şu ifadelerle açıklamıştır.

“Öğretmenlik çocuğa hayatı ögretmektir. Bunun içinde yalnızca bilgi yok, hayat var. Toplum içinde kabul görme var. Doğru davranışlar sergileme var. Öğretmen bunlarl da ögretmelidir. Başkalarına saygl duyma, eğitimli insanların özellikleri yani bunlarl da ögretmelidir”.

Ö11'in ifadesinden öğretmenin görevinin yalnızca bilgi değil hayata dair her şeyi öğretmek olarak gördüğü bilgi ve davranışların kazanımından çok öğretilebileceğine dair söylemi davranışçı yaklaşımın hala etkisini sürdürdüğünün bir göstergesi olarak kabul edilebilir.

Öğrenci ile gerçek anlamda ilgilenebilmek için öğrencilerin tanınması gerektiğini ifade eden çok az sayıda öğretmenden Ö41 görüşünü şu şekilde açıklamıştır.

"Çocukla ilgilenmek çocuğu ailesi yaşadı̆̆ yer, ekonomik özellikleri ile tanımak ve etkinliklerini buna uygun olarak yapmak, ya da ödevleri buna uygun olarak vermek demektir. Çocuğun durumu yoksa internetten araştırma ödevi vermek kötü olur mesela bunu bilmek önemli. Ya da anne babasının eğitim durumu ödevine yardım etmesi için yeterli değilseçocuk ödevini yapmakta zorlanabilir. Bunlar geliyor aklıma. Bunları bilirsek ögretimi daha kolay yaparız diye düşünüyorum"

\section{2. İkinci alt probleme ilişkin bulgular}

İkinci alt probleme ilişkin olarak veliye göre kendisinin ve öğretmeninin çocukla ilgilenmesinin yükledikleri anlamlar bağlamında vermiş oldukları cevaplara ilişkin bulgular Tablo 3 'te verilmiştir. 
Tablo 3: Velinin çocukla ilgilenmeye yönelik görüşleri

\begin{tabular}{|c|c|c|c|}
\hline $\begin{array}{l}\text { Veliye göre öğretmenin çocukla } \\
\text { ilgilenmesi }\end{array}$ & $\mathbf{f}$ & $\begin{array}{l}\text { Veliye göre kendisinin çocuğuyla } \\
\text { ilgilenmesi }\end{array}$ & $\mathbf{f}$ \\
\hline Çocuğun başarısı için uğraşması & 43 & $\begin{array}{l}\text { İhtiyaçlarını karşılama (öğretmenin } \\
\text { isteklerini alma, okul harçlığı verme, } \\
\text { kıyafet alma) }\end{array}$ & 46 \\
\hline Bilgi öğretmesi & 42 & Ahlaki değer verme & 39 \\
\hline \multirow[t]{2}{*}{ Ödev vermesi } & 31 & Sevdiğini gösterme & 39 \\
\hline & & $\begin{array}{l}\text { Sorunlarıyla ilgilenme (soru sorma, } \\
\text { çözüm arama) }\end{array}$ & 39 \\
\hline Ödevleri kontrol etmesi & 31 & $\begin{array}{l}\text { İsteklerini karşılama (en yeni } \\
\text { teknolojileri, cep telefonu, bilgisayar, } \\
\text { tablet, bilgisayar oyunu alma) }\end{array}$ & 31 \\
\hline Başarı için test çözdürmesi & 28 & Ödevlerine yardım & 26 \\
\hline $\begin{array}{l}\text { Çocuğunun başarıları takdir etmesi } \\
\text { (aferin, tebrikler) }\end{array}$ & 27 & $\begin{array}{l}\text { Çocuğuyla İyi iletişim kurma } \\
\text { (kızmama, bağırmama, dinleme, } \\
\text { kendisini ifade etmesine firsat verme) }\end{array}$ & 25 \\
\hline Ahlaki değer kazandırması & 27 & $\begin{array}{l}\text { Çocuğun başarısını takdir etme } \\
\text { (tebrikler, aferin daha iyisini yaparsın) }\end{array}$ & 25 \\
\hline Çocuğun dokunulmazlığını koruması & 23 & Test çözdürme & 24 \\
\hline
\end{tabular}

(şiddet uygulamama, kızmama,

bağırmama ve cezalandırmama)

Veliyi ödevler konusunda doğru

bilgilendirmesi

16 Eğitimini destekleme (okula getirip götürme, okul çantasını hazırlama, çocuğunun okula devamı takip etme ve okulda yaptıklarını sorma)

Veli ile iyi iletişim kurması

14 Ödülllendirme

(aşağılamama, saygı duyma, doğru hitap etme)

Çocuğa özgüven kazandırması

13 Çocuğun meslek sahibi olması için çaba (maddi imkanlarını zorlama)

Güvenliğini sağlaması

Çocuğa yardım etmesi (çözemediği

13 Birlikte zaman geçirme

13 Güvenliğini sağlama ve koruma soruları çözmesi için)

Başarısız öğrenciler nedeniyle başarılı öğrencilerin motivasyonlarını

$8 \quad$ Sağl1k kontrolü ve takibi

düşürmemesi

Güvenliğini sağlaması (derste ve tenefüste)

7

Sosyal aktiviteler düzenlemesi (oyuna, tiyatroya vb.götürme)

$7 \quad$ Huzurlu ev ortamı sunma

Öğretmen ile iletişim kurma

Öğrenciyi tanıması (ailesi ve

(Öğretmen çağırdığında gitme)

imkanları ile)

Disiplin sağlama

Disiplin sağlaması

2

Tablo 3 incelendiğinde öğretmenlerinin çocukları ile ilgilenmesinin ne anlama geldiğine ilişkin sorulan soruyu velilerin çoğunun çocuklarının akademik başarısı için öğretmenin öğretme çabası ile açıkladıkları görülmektedir. Yine velilerin çoğunun ödev verme ve ödev kontrolü yapma, test çözdürme gibi akademik başarıyı arttıracağını düşündükleri ifadeler kullandıkları görülmektedir. Velilerin yarısından fazlasının öğretmenin çocukla ilgilenmesini; çocuğunun başarısını takdir etmesi ve ahlaki değer kazandırması ile ilişkilendirdiğgi; çocuğun 
dokunulmazlığını korumasının da veliler açısından önemsenen bir başka özellik olduğu görülmektedir. Velilerin bir kısmının öğretmenlerin çocukları ile ilgilenmesini, verdikleri ödevler ve ödevlerin nasıl yapılması gerektiği konusunda velileri yazılı olarak bilgilendirmesi, veliler ile doğru iletişim kurması, çocuğuna özgüven kazandırması, çocuğuna yardım etmesi, başarısız öğrenciler nedeniyle başarılı öğrencilerin motivasyonlarını düşürmemesi gibi ifadelerle açıkladıkları görülmektedir. Velilerin çok azının çocuğun güvenliğini sağlama, sosyal aktiviteler düzenleme ve özellikle de çocuğunu tanıyarak eğitim öğretim faaliyetleri düzenleme gibi öğretmen davranışlarına, iki veli de kurallar koyarak disiplin sağlamanın önemine ilişkin ifade kullandığı görülmektedir.

Öğretmen ilgisini öğretmek kavramıyla ilişkilendiren V11 görüşünü şu şekilde açıklamıştır

“Öğretmen öğretendir, yeri geldiğinde ana babadır, bir şeyler ögretmek, öğretmek.Bizim ögrretemediğimiz bilgileri ögretmek demektir çocukla ilgilenmek bence" şeklinde ifade ederken V24 "çocuklarımızın sınavlarda başarılı olabilmeleri için bol bol test çözmesi gerekiyor. Öğretmenin derste test çözdürmesi, ödev olarak da vermesi gerekir. Çocuğumun gelişimi için sınavlara girmesi alışması lazım. Öğretmene hep bunu söylüyorum. Çocuğum geçenlerde bir deneme sinavına girdi. Kaydırdım diyor, birinci olacaktım diyor. Öğretmen daha fazla test çözdürsün ki çocuğum birinci olabilsin"

Velilerin çocukları ile ilgilenmeyi daha çok çocuklarının ihtiyaçlarını karşılama ile ilişkilendirdikleri,sonra sırasıyla ahlaki değer kazandırma, sevme ve sorunları ile ilgilenme, isteklerini karşılama gibi ifadelerle açıkladıkları görülmektedir. Velilerin ifadelerinden eğitim ve öğretim faaliyetleri ile ilişsili olarak kendilerine düşen görevi daha çok ödevlere yardım etme ve test çözdürme olarak gördükleri, eğitimin desteklenmesini ise okula getirip götürme, okul çantasını hazırlama, çocuğunun okula devamı takip etme ve okulda yaptıklarını sorma, çocukla iyi iletişim kurma, başarısını takdir etme, çocuğunun meslek sahibi olması çaba ile güvenliğini sağlama ve koruma gibi gibi davranışlarla ilişkilendirdikleri anlaşılmaktadır. Çok az veli tarafından sözü edilen birlikte yemeğe ya da gezmeye gitme gibi aktivitelerle birlikte zaman geçirmenin de ilgilenmek anlamında kullanıldığ 1 görülmektedir. Güvenlik ve koruma, sağlık kontrolü, huzurlu bir ev ortamı sunma disiplin çok az veli tarafından dile getirilirken, öğretmenle iletişimin öğretmen çağırdığında öğretmenle görüşme şeklinde yine yok denecek kadar veli tarafından dile getirilmesi ve velinin çocuğuyle ilişskilendirdiği ifadelerin eğitimsel bir ilişkiden uzak olması dikkat çekmektedir.

Çocuğu ile ilgilenmeyi ihtiyaç ve isteklerini karşılama ile ilişkilendiren velilerden V50 çocuğun teknolojik araçlara yönelik ihtiyacını gidermek ile açıklarken V38 istek ve ihtiyaçlarını karşılayamadığı için çocuğu ile ilgilenemediğini düşündüğünü belirtmiştir. 
V50 “Çocuğumla ilgilenmek onu okulda mahcup etmemektir. Misal öğretmen bir ödev veriyormuş çocuğumun bazı arkadaşları bilgisayardan bakıp yapıyormuş, bizimki yapamayınca öğretmen öbürününkünü daha çok beğeninde ăgllyor. Ben alamadım bilgisayarı çocuğum bu yüzden geri kalıyor. Şimdi onu almak için başkalaının işlerinde de çalışıyorum alayım çocuğum da ödevlerini yapsin mahcup olmasin."

V38 "Çocuğuma fazla bir ilgi gösteremiyorum. Dersine fazla yardımcı olamıyorum. Dersine çalıştıramıyorum, istediği şekilde her yere götüremiyorum çocuğumu, kendimiz çalıştı̆̆ımızdan her yere götüremiyorum çocuğumu. Çocuğum ömründe sinema nedir bilmez bir lunapark nedir bilmez. Ne kendime bi özel günüm var ne de çocuklarıma var.... Çocuğumun iyi düzenli terbiyeli bir hayatı olsun istiyorum ben kendim veremiyorum kimseyi de yargllamıyorum... para ilgi değil çocuğa bi slcak yanaşmak. Çocuğa tatlı dil, güler yüz, sevgiyi saygıyı öğretecek. Ben okuyamadım iki gün okula gidiyorsam üç gün gidemiyordum iş güç... benim fazla bir bilgim yok. Eşimde fazla ilgilenmiyor. Ben size para veriyorum ya diyor. Durum bu."

Çocukları ile ilgilenmeyi, onların eğitimine destek verebilmek için imkânlarını seferber etme olarak açıklayan veliler olduğu görülmektedir. $\mathrm{Bu}$ velilerden V2 eğitime desteği maddi destek ile ilişkilendirerek görüşünü şu şekilde açıklamıştır.

"Çocuklarımızın okumasını istiyoruz, iyi bir yerlere gelmelerini istiyoruz. Rezil olmasınlar biz gibi,biz okumadık el kapısinda çalışmakla olmuyor yani, okumalarını istiyoruz yani. Bu yüzden okumaları için elimizden geleni yapıyoruz. Ilgilenmek bence ĕgitimiyle ilgilenmektir. Ĕ̈itimi için biz bir şey yapamıyoruz. Ö̆gretmenlerimiz bilgi ögretsinler, biz de defter kitap ne gerekirse alalım"

Velilerden çocuğun eğitimi ile ilgilenmeyi sadece okulla ilgili sorular sorma, ya da çocuk soru sorarsa cevap verme ile açıklayan veliler de olduğu anlaşılmaktadır. Bu velilerden V3 ilgilenmeyi şu şekilde açıklamıştır.

"Soruyorum okul nasıl geçti, arkadaşlarınla nasıl geçti... Bazen ben ona kitap okuyorum, mesela ben işimi yaptı̆̆ımda bulaşık falan yıkarken geliyor bana bir şey sorduğunda dönüp bakıyorum cevap veriyorum. Yanımda duruyor ders çallşıyor, bazen bana bir şeyler soruyor. Yapabildiğimi söylüyorum zaten yapamadı̆̆ımı söylüyorum yani..."

Çocukla ilgilenmeyi onun okul ihtiyaçlarını karşılamakla açıklayan V5 çocuğun okul ihtiyaçlarını almak için şartlarını zorladığını bunun ise en büyük ilgi olduğunu düşündüğünü şu ifadelerle açıklamıştır. 
"Çocuğumuzla eğitimi için çok ilgileniyoruz. Çocuk okula gidecek öğretmen bu alınacak dedi mi illa o alınacak yoksa ben gitmem diyor. O zaman da onu almak için bazen diğer ihtiyaçlarımızdan kislyoruz allyoruz."

Veli ilgisini öğretmen ile iletişim kurma ile açıklayan V37 nin aşağıdaki ifadesi velinin öğretmen ile görüşmesini çocuğun gelişimi ile ilgili olarak kendisinin yapması gerekenler ve katkılar ile değil de sorun olursa müdahale etme olarak gördüğünü ortaya koymaktadır

"Biz ĕgitimden ne anlarız. Öğretmen öğretiyor ĕgitiyor. Ama ögretmen çă̆lrırsa bir sorun var demektir, hemen gideriz, ilgileniriz. Çocuk öğretmenin dediklerini yapmazsa öğretmen çă̆ırır biz de çocuğumuzla konuşuruz. Öğretmen çă̆ırmazsa çocuğun bir sorunu yoktur diye seviniriz"

\section{3. Üçüncü alt probleme ilişkin bulgular}

Üçüncü alt problemle ilgili olarak çocukların velisi ve öğretmeninin kendisiyle ilgilenmesine yükledikleri anlamlar bağlamında vermiş oldukları cevaplara ilişkin bulgular Tablo 4'te verilmiştir.

Tablo 4: Çocuğun kendisiyle ilgilenilmesine ilişkin görüşleri

\begin{tabular}{|c|c|c|c|}
\hline Öğretmeninin ilgilenmesi & $f$ & Velisinin ilgilenmesi & $f$ \\
\hline $\begin{array}{l}\text { Sevdiğini göstermesi (öpmesi, elini tutması, } \\
\text { gülümsemesi, yüzünü okşaması, sevdiğini } \\
\text { söylemesi) }\end{array}$ & 43 & $\begin{array}{l}\text { Sevdiğini göstermesi(öpmesi, okşaması, } \\
\text { elini tutması, sevdiğini söylemesi, saçını } \\
\text { taraması) }\end{array}$ & 49 \\
\hline $\begin{array}{l}\text { Çocuk ile iyi iletişim kurması(kızmama } \\
\text { bağırmama ve güzel konuşma ) }\end{array}$ & 40 & $\begin{array}{l}\text { Mutlu etmesi (istediğini alma-bilgisayar } \\
\text { tablet, ücretli tablet oyunlar) } \\
\text { Ödevlerine yardım etmesi }\end{array}$ & $\begin{array}{l}45 \\
45\end{array}$ \\
\hline $\begin{array}{l}\text { Bilgi ögretmesi (okuma, yazma, matematik } \\
\text { vb yere çöp atmama, sınıfi temiz tutma) }\end{array}$ & 40 & $\begin{array}{l}\text { Başarı beklentisi ve desteği (sana } \\
\text { güveniyorum yaparsın) }\end{array}$ & 43 \\
\hline Doğum gününü hatırlama ve kutlama & 40 & $\begin{array}{l}\text { Hediyeler alması (tablet, bilgisayar, } \\
\text { bilgisayar oyunları, oyuncak) }\end{array}$ & 41 \\
\hline $\begin{array}{l}\text { Başarı beklentisi ve motivasyon (sana } \\
\text { güveniyorum, yaparsin demesi) }\end{array}$ & 38 & Doğum gününü hatırlama ve kutlama & 40 \\
\hline Dikkate alması ve dinlemesi & 37 & İhtiyaçların karşılanması (harçlık vermesi) & 39 \\
\hline Ödev vermesi ve kontrol etmesi & 36 & $\begin{array}{l}\text { İyi iletişim kurması (dinlemesi, emir yerine } \\
\text { rica cümleleri kurma) }\end{array}$ & 37 \\
\hline Sorunlarıyla ilgilemesi & 33 & Tüm çocuklarına eşit yaklaşma & 34 \\
\hline $\begin{array}{l}\text { Takdir etmesi, başarısını övmesi (aferin, } \\
\text { tebrikler alkışlatması vb.) }\end{array}$ & 30 & $\begin{array}{l}\text { Eğitimini desteklemesi (öğretmenin } \\
\text { istediği okul ihtiyaçlarını alması, kursa } \\
\text { göndermesi) }\end{array}$ & 32 \\
\hline $\begin{array}{l}\text { Özel olduğunu önemsediğini hissettirme (bir } \\
\text { yere gönderileceği zaman kendisini tercih } \\
\text { etme, sunuculuk yaptırma) }\end{array}$ & 28 & Sorunlarıyla ilgilenmesi & 30 \\
\hline $\begin{array}{l}\text { Eğlenceli ders işlemesi (birlikte etkinlik } \\
\text { yapma, oyunlara katılma) }\end{array}$ & 25 & $\begin{array}{l}\text { İzin vermesi (bilgisayar oynamasına, tv } \\
\text { izlemesine ,bir yere gitme, işyerine gelme) }\end{array}$ & 28 \\
\hline $\begin{array}{l}\text { Ödül vermesi (Şeker, çikolata vb. maddi } \\
\text { ödüller ve-yıldı, imza, çıkartmalar gibi } \\
\text { simgesel manevi ödüller) }\end{array}$ & 24 & $\begin{array}{l}\text { Takdir-başarısını övme (Tebrikler, aferin } \\
\text { vb.) }\end{array}$ & 24 \\
\hline $\begin{array}{l}\text { Tüm öğrencilere adil eşit ve tarafsız olması } \\
\text { (tahtaya kaldırma ve söz hakkı verme) }\end{array}$ & 24 & Huzurlu ev ortamı sunma & 24 \\
\hline $\begin{array}{l}\text { Sosyal aktiviteler düzenleme (gezi, tiyatroya } \\
\text { götürme ) }\end{array}$ & 22 & $\begin{array}{l}\text { Birlikte zaman geçirme (parka, lunaparka, } \\
\text { gezmeye götürme, sinema-tiyatroya gitme) }\end{array}$ & 22 \\
\hline
\end{tabular}


Hediye verme

Derslerinde yardım etmesi (sorularına cevap vermesi, çözemediği soruları çözmesi)

Haksızlık yapmaması (haksı yere ceza vermemesi)

Güvenliği sağlanması (okuldaki tehlikelerden koruma, okuldaki diğer çocuklardan koruma)

İyi öğrenci olarak nitelendirme (başarılı öğrencilerin bulunduğu kümeye alması)

Örnek olması(kitap okuması)

Sağlığı ile ilgilenmesi (hasta olduğunda ailesini aramasi

Veli ile daha sık görüşme

Ceza vermemesi (kavga edeni tenefüse çıkarmama, fazla ödev verme)

İzin vermesi (tuvalete gitmeye, oyun 9 oynamaya, kalem açmaya)

Tablo 4 incelendiğinde çocuğun kendisiyle ilgilenilmesine yönelik olarak öğretmeni ve velisinden beklentilerini görmek mümkündür. Çocukların öğretmenlerinden beklediği en önemli şeyin sevgi göstermesi olduğu, iyi iletişim kurmalarının ise güzel konuşma beklentisi ile ikinci sırada yer aldığı görülmektedir. Bilgi öğretmenin de ilgilenmek anlamında önemli görüldüğü, doğum günü hatırlama, başarı beklentisi ve desteği ve dikkate alınmanın duygusal beklentiyi karşılaması açısından birçok öğrenci tarafından önemli görüldüğü anlaşılmaktadır. Eğitim öğretimle ilişkili olarak ödev verme ve kontrol etme yarıdan fazla öğrencinin ilgilenmek kavramıyla ilişkilendirdiği bir öğretmen davranışı iken, sorunlarıyla ilgilenme, başarısını takdir etme ve övme, bir ve özel olduğunu hissettirme, gibi davranışların da birçok öğrenci için ilgilenmek kavramı ile ilişkilendirildiği görülmektedir. Derslerin eğlenceli işlenmesi, ödül vermesi de birçok öğrencinin ilgi beklentisi olduğu görülmektedir. Yine birçok öğrenci için öğretmenin adaletli ve eşit davranması, sosyal aktiviteler düzenlemesi, hediye vermesi, derslerine yardım etmesi ve haksızlık yapmamasının da öğrenciler açısından önemli görüldüğü anlaşılmaktadır. Öğretmenin okulda güvenliği sağlaması, iyi öğrenci olarak nitelendirmesi, örnek olması, ailesi ile daha sık görüşmesi, sağlığ i ile ilgilenmesi, yapılan bir davranışa yönelik ceza vermemesi ve izin vermesinin bazı öğrenciler tarafından ilgilenme ile ilişkilendirildiği görülmektedir.

Çocuk açısından velisinin kendisiyle ilgilenmesi daha çok sevdiğini göstermesi ve istediklerini almak yoluyla kendisini mutlu etmesi ile ilişkilendirilmiştir. Çocuğun velisinden ğitimsel anlamda beklentisi ödevlerine yardım etmesi ve başarı beklentisi ve desteği iken hediyeler alması, doğum gününü kutlaması, ekonomik ihtiyaçların karşılanması, eğitimin desteklenmesini de okul ihtiyaçlarının karşılanması ile ilişkilendirmeleri gibi ifadelerin daha daha fazla yer bulması çocuğun ilgilenmek kavramını daha çok maddi beklentilerle ilişkilendirdiğini ortaya koymaktadır.Çocukların bir kısmınınvelisinin kendisiyle ilgilenmesini, iyi iletişim kurma, tüm çocuklarına eşit yaklaşma, sorunlarıyla ilgilenme, başarısını takdir etme, huzurlu ev ortamı sunma, birlikte vakit geçirme 
gibi duygusal; teknolojik araçlarla daha çok vakit geçirmesine izin vermesi yanında eğitim süreci ile ilişki kurulması mümkün görülmeyen kişisel eşyaların kullanımı gibi maddesel beklenti ve istekleriyle ilişkilendirdikleri görülmektedir.

Kendisi ile ilgilenmenin kendisine bir şeyler alma ya da teknolojik araçlara ulaşma imkânı sağlama olarak açıklayan öğrencilerden Ç17 şu ifadeleri kullanmıştır.

"Babamin ya da annemin bana isteklerimi alması ya da istediklerimi yapması benim için ilgilenmek demektir. Mesela bana tablet ya da bilgisayar alması. Ama şimdi alamazlar. Bu yüzden de ben babamın işyerindeki bilgisayarla oynamak için onun işyerine gitmek isterim. Babam da beni götürür. Benimle ilgilenir”

Dikkat çekici bir ifade olarak huzurlu bir ev ortamı sunmanın ilgilenmekle eş değer olduğunu ifade eden Ç34 bu görüşünü şu şekilde ifade etmiştir.

"Annemle babamin benimle ilgilenmesi beni düşünmesi demek kavga etmemeleri, ben ders çalışırken ilgimi dağıtmamalarıdır. Çünkü ben ders çalışmak istesem de onlar kavga ederlerken çalışamıyorum. Benimle ilgilenmek istiyorlarsa kavga etmesinler yeter."

Oyuncakları ile daha uzun süre oynama, korunma ihtiyacı, onun için bir şeyler yapma, hasta olduğunda okula göndermeme, kitap okuyarak örnek olma, beslenme ihtiyacının karşılanması da sırasıyla ilgilenmek kavramını açıklamak için kullandıkları ifadeler arasında görülmektedir. Çocuklarının bir kısmının ebeveynlerinin kişisel eşyalarına ya da yaş ve gelişim özelliklerine göre kullanmaları mümkün olmayacak eşyaların kullanımını bile sınırsız isteklerin karşılanmasını ilgilenmek kavramı ile ilişkilendirebileceğini ortaya koymaktadır. Babasının otomobilini kullanmak isteyen öğrencilerden Ç48 bu ilişkilendirmeyi şu şekilde ortaya koymuştur.

"Bazı babalar çocuklarına araba kullandırıyor. Ben de kullanmak istiyorum. Kaza yaparsak masraf çıkar belki ama bazı babalar bunu hiç düşünmüyor. Çocuğunu çok sevdiği için izin veriyor. Benim de babamın ilgilenmesi demek parayı değil beni düşünmesi demek. Keşke izin verse, ben de anlarım ilgilendiğini."

\section{TARTIŞMA ve SONUÇ}

Hızlı bir değişimin ve dönüşümün yaşandığ 1 günümüzde toplumlar, sosyal, siyasal, kültürel, ekonomik vb. yönlerden çeşitli gelişmelere tanıklık etmektedirler (Genç ve Eryaman,2008). Bu gelişmeler eğitim anlayışında da değişikliklere neden olmuş ve öğreneni merkeze alan bir eğitim anlayışının benimsenmesi gereğini doğurmuştur. Ancak herhangi bir eğitim anlayışının benimsenmiş olması etkili bir eğitim için tek başına yeterli değildir; öğrenci, öğretmen, toplumsal yap1, aile ve okulların, bu anlayışa uygun olarak kendilerini yenilemeleri de gerekmektedir. Öğrenmenin bireysel faktörlerle ilişkisi ve eğitim öğretim ortamlarının değişen amacı olarak ortaya çıkmasıyla birlikte, öğrenme yaklaşımı, öğrenme öğretme süreci, değerlendirme, öğretmen rolü, disiplin yaklaşımları, sınıfın iletişim yapısı, fiziksel düzeni ve örgütlemeye ilişkin yapısı da bir dönüşüm içine girmiştir. Bu öğeler birbirleriyle bütünsel bir ilişki içindedirler; birisinde 
gerçekleşen bir değişim diğer tüm öğeleri etkiler (Özer ve Kalayc1,2012). Eğitim reformunun hedeflerine ulaşıp ulaşmadığını belirlemede, değişim süreci içinde yer alan tüm bileşenlerin (okul, öğrenci, öğretmen, veli) değişimin dinamiğini anlaması ve ilişkili olduğu birey ya da örgüte anlamlı bir şekilde aktarması oldukça önemlidir (Fullan, 1991'den akt: Han, 2013). Günümüzde değişen eğitim anlayış1 özellikle öğretmen ve aileden çocuğu merkeze alarak her yönden ilgilenmelerini beklemektedir. Yapılandırmacı öğrenme yaklaşımının öngördüğü anlamda çocukla ilgilenmek, çocuğun ilgi, ihtiyaç ve beklentileri dikkate alınarak öğrenme ortamlarının hazırlanması, öğrenenin öğrenmesini kolaylaştırıcı ortamların oluşturulması anlamına gelmektedir.

Eğitim reformunun uygulayıcısı olacak öğretmenler ve onların reforma yaklaşımı, stratejik rolleri nedeniyle değişimin sonuçlarını doğrudan etkilemektedir. Öğretmenlerin eğitim reformunu nasıl algıladığı ve uyguladı̆̆ aslında reformun hedeflerine ulaşıp ulaşmadığı sorusuna yanıt verebilir (Sikes, 1992'den Akt: Han,2013).

İlgili alanyazın incelendiğinde, birçok çalışmada öğretim etkinliklerinin, öğrencinin bilgi birikimi, motivasyon ilgi ve ihtiyaçlarına uygun olarak planlanması gerektiği bulgusuna ulaşıldığı görülmüştür (Yeşilyurt,2011). Ihtiyaç kavramı yapılandırmacı öğrenme yaklaşımı açısından öğrencinin daha çok öğrenme ihtiyacı olarak ele alınabilir. Öğrenme ihtiyacı ise bireyin yeni bilgiyi yapılandırabilmesi için hali hazırda var olan bilgi ve becerilerindeki eksiklerdir. Öğrenci ne biliyor ya da yapabiliyor;ne bilmesi ve yapabilmesi gereklidir ya da öğrenmesi için ne tür öğrenme ortamlarına ihtiyacı vardır sorularına verilebilecek cevaplardır. Zihinsel yapılandırma sürecinde rehberliğin doğru şekilde gerçekleşebilmesi için öğrencilerin öğrenme ihtiyaçlarının belirlenmesi gereklidir. Öğrenci bir öğrenme için hazır değil ise öğrenmek istediği veya öğrenmesi istenen durum/konu ile ilgili sıkıntılar yaşaması muhtemeldir. Öğrenenin öğrenmesini ve zihinsel yapılandırmasını etkileyen faktörler arasında görülen bilgi birikimiAusubel'e göre öğrenmeyi etkileyen en önemli faktör olarak görülmektedir. Yapılandırmacı öğrenme kuramı da bu düşünceyle; öğrenmeyi öğrencilerin bu birikimi kullanarak yeni bilgi edinmeleri ve kendine özgü bilgi oluşturmalarıyla açıklayan bir öğrenme kuramı olarak kabul edilmektedir (Hand ve Treagust, 1991; Appleton, 1997'den akt: Özmen, 2004). Ancak araştırma bulguları incelendiğinde öğrenme öğretme ortamından öğretmen ve velinin ilk beklentisinin akademik başarı olmasına rağmen akademik başarıya götürecek olan bilgi birikimi ve öğrenme ihtiyacına ilişkin herhangi bir ifadeye rastlanamaış olması dikkat çekicidir.

Yapılandırmacı eğitim anlayışının ilk amacı bir öğrencinin bilgi edinmesi gereken bir konuya ilgisini çekmektir. Bir motivasyon değişkeni olarak ilgi, bireyin belirli bir konu içeriğiyle etkileşimi (Lipstein ve Renninger, 2006), bir işi yapmaya ve başarmaya yönelik istek, dikkat, çabanın şekillendirdiği psikolojik eğilim olarak tanımlanabilirken (Hidi, 2000; Renninger, 2000) bireyin bir davranış için istekli hale gelmesini sağlayan öğrenen davranışlarının yönünü, şiddetini, kararlılığını belirleyen en önemli güçlerden birisi (Arıklı ve Yorganc1, 2012), bireylerin kendilerine karşı yapılan davranışlardan etkilenme durumu ve iş hakkındaki hisleridir (Keenan, 1996). Öğrenciler, herhangi bir konuya ilgi duyduklarında o konuya dikkatlerini toplarlar, o konuda çalışmaya ilişkin amaçlar 
belirleyerek öğrenmeye ilişkin çeşitli stratejiler geliştirebilirler (Hidi ve Renninger, 2006'den akt: Meşe, Özer, Dindar, ve Odabaş1,2014).

Alanyazında bireyin dışarıdan hiçbir etkileme çabası olmaksızın bir şeye yönelme hali için bireysel ilgi, dış etkenler tarafından bireyin bir alana yönelmesi durumu için ise durumsal ilgi kavramlarının kullanıldığı görülmektedir (Krapp, Hidi ve Renninger, 1992). Çocuğun öğrenme ortamına yönelik bireysel ilgisi ve öğrencinin sınıf içi öğrenme ortamına yönelik algısı ve sınıf içi ortamla olan etkileşimine yön veren durumsal ilgisinin oluşturulması ve sürdürülmesi öğretmenle ve öğretmenin oluşturacağı öğrenme ortamları ile ilişkilendirilebilmektedir (Linnenbrink-Garcia ve diğerleri, 2010; Shen ve Chen, 2006) Öğrencinin yeni bilgilerle mevcut bilgi birikimi arasında bağlantı kurabilmesi için öğrenme ortamının da bu sürece hizmet etmesi gerekmektedir. İlgi ve dikkat çekici öğretim materyali ile bilişsel kaynaklar arasındaki ilişkinin varlığını ortaya koyan ve öğrenci ilgisinin öğrenme ortamında değerlendirilmesi gerektiğini vurgulayan ve öğrencilerde ilginin geliştirilebileceğini gösteren çalışmalar göz önünde bulundurulduğunda öğretmenlerin, öğrencilerinin ilgi alanlarına uygun öğrenme ortamları hazırlayarak motivasyonlarını ve derse ilişkin ilgilerini arttırabileceği söylenebilmektedir (Krapp, 1999; Pintrich ve Schunk, 1996, Renninger ve Hidi, 2002; Renninger, Sansone ve Smith, 2004, Schiefele, 1998'den akt: Meşe, Özer, Dindar, ve Odabaşı, 2014). Bu nedenle öğretmenlerin konuya ya da derse değil kendi öğrenmesi üzerinde düşünen bireyler üzerinde yoğunlaşması gerekmektedir Çünkü öğrenenlerin kendi deneyimlerine vermiş oldukları anlamlardan bağımsız bir bilgi yoktur (Hein, 1991'den akt: Arslan, 2010). Ancak araştırma bulguları incelendiğinde öğrencilerin bireysel ilgi alanlarını belirleyerek ya da durumsal ilgi yaratacak öğrenme ortamlarına öğretmenlerin hiç birinin değinmedikleri yalnızca az sayıda öğretmenin çocuğun tanınması gerektiğine ilişkin çok genel ifadeler kullandığı, velilerin de öğretmenlerden bu duruma ilişkin bir beklentisinin olmadığı görülmektedir. Öğretmenlerin hizmet yılları göz önünde bulundurulduğunda davranışçı öğrenme kuramının öğretileriyle öğrenim süreçlerini tamamlamış olmaları; velilerin de bu duruma ilişkin bir ifade kullanmamış olmamaları gerek öğrenim durumları nedeniyle gerekse iş alanları nedeniyle eğitim süreci ile ilgili olarak yeterince bilgi sahibi olmamaları ile ilişkilendirilebilir. Çocukların da ne öğretmenlerinden ne de ailelerinden ilgi alanlarının, dikkate alındığı eğitim ortamlarının oluşturulması yönünde birbeklenti içinde olmamaları ve herhangi bir ifade kullanmamaları onların içinde bulunduğu yaş, gelişim özellikleri ve yaşanılan zamanın tercihleri üzerindeki etkileri ile açıklanabilir.

Yine araştırma bulgularına göre; öğretmen, veli ve çocukların bireyin bilgiyi yapılandırmasını etkileyen içsel faktörler olan bilgi birikimi ve öğrenme ihtiyacı ile bu faktörleri etkili bir şekilde işe koşacak olan yapılandırmacı öğrenme ortamlarına neredeyse hiç değinmedikleri söylenebilir. İlgili alanyazın incelendiğinde, yapılandırmacı yaklaşımın sınıf ortamında uygulanmasına ilişkin özellikle 3E, 4 E, 5E,7E gibi modeller geliştirilmiş olduğu görülmektedir (Özmen, 2004). 3E, 4E, 5E ve 7E modelleri kapsamında değerlendirilen bu modellerden keşfetme, kavramlaştırma ve kavramın uygulanması şeklinde 3 aşamalı gerçekleştirilen 3E modeli öğrenme halkası, üzerinde yeni çalışmalar yapıldıkça 
sırasıyla 4E, 5E ve 7E öğrenme halkalarına geçilmiştir (Bybee ve diğerleri, 2006'dan akt: Köksal, 2014). 5E basamağındaki, konuya girme, keşfetme, açıklama, derinleştirme ve değerlendirme aşamalarına, konuya girişten önce ön bilgileri yoklama ve elde edilen verileri ilişkilendirip değerlendirmenin yapıldığı basamaklar da eklenerek 5E modelinin geliştirilmiş formu 7E uygulamaya konulmuştur. Bu uygulama modellerinden $5 \mathrm{E}$ ve $7 \mathrm{E}$ modellerinde, öğrencilerin ilgilerinin çekilerek ön bilgilerinin ortaya çıkarıldığı Girme-merak uyandırma aşamasında öğretmen öğrencileri düşünmeye yönlendirerek ve var olan bilgilerini açığa çıkartmaya çalışarak öğrencilerin ne bildiklerini görmelerini amaçlar (Bybee,2003).Keşfetme aşaması, öğretmenin bir danışman rolünde öğrencilerini izleyip herhangi bir değerlendirme kaygısı gütmeden dönütler verdiği, (Eisenkraft, 2003), deneyler, grup tartışmaları, gezi gözlem gibi öğretim yöntem ve tekniklerini kullanarak soruların çözümüne yardımcı olduğu, öğrencilerinin kendi kendilerine bazı bilgilere ulaşmalarını sağladığı aşamadır (Özmen, 2002; Kabapınar, Sapmaz ve Bıkmaz, 2003; Newby, 2004). Açıklama aşaması; öğretmenin öğrencilerin deneyimlerini bir araya getirmelerinde, buldukları sonuçları açıklamada ve yeni kavramlar oluşturmalarına yardımcı olmak için temel bilgi düzeyinde açıklamalarda bulunduğu, öğrenci gözlemleri kullanılarak konuyla ilgili bilimsel kavramların sunulduğu ve açıklandığı bir basamaktır. Derinleştirme aşamasında ise, öğrencilerin yeni sınıflandırma, tanımlama, açıklama ve yeteneklerini benzer durumlara transfer etme ve uygulama olanağ buldukları deneysel sorgulama, inceleme projeleri, problem çözümü ve karar verme etkinliklerini kapsar. Bu basamakta öğrencilere bir önceki basamaklarda edindikleri yeni fikirleri benzer durumlarda uygulama ve kullanma firsatı verilip yeni kazanılan bilgi ve becerilerin pekiştirmeleri amaçlanır (Özmen, 2002; Newby, 2004).7 E modelinde yer bulan ilişkilendirme aşaması, var olan bilgilerin yeni bilgiler ile ilişkilendirilme sürecini ifade eder. Yine $7 \mathrm{E}$ modelinde yer bulan paylaşma/ değişim aşaması, öğrencilerin bir problemin birlikte üstesinden gelebilmenin yollarını aradıkları interaktif bir süreç olarak görülmektedir (Köksal,2014). Değerlendirme aşaması ise öğrencilerin yeni kavram ve becerilerin ne kadar öğrenildiğini ve kendi gelişimlerini değerlendirdiği basamaktır (Özmen, 2002'den akt: Ağgül-Yalçın ve Bayrakçeçen,2010). Bu modellerin işlem basamakları tüm dersler için de geçerli hale getirilebilir. Örneğin Türkçe dersinde süreç temelli yazma etkinlikleri bu işlem basamakları ile ilişkilendirilerek yürütülebilir. Ancak araştırma bulgularına göre hem öğretmen hem veli hem de çocuğun akademik anlamda ilgilenmek kavramından anladıkları şeyin çoğunlukla "bilgi öğretmek" olduğu anlaşılmaktadır. Öğrencinin öğrenmesini sağlayıcı öğrenme ortamlarından söz edilmediği görülmektedir. "Bilginin öğretilmesi "davranışçı kuramın öngörüsüdür. Yapılandırmac1 yaklaşımın öngördüğü "bilginin yapılandırılması" ifadesi ile çelişmektedir. $\mathrm{Bu}$ durum da Türkiye'de 2004-2005 programı ile uygulanmaya başlayan yapılandırmacı öğrenme yaklaşımının öğrenme ortamlarına yansıtılamadığını göstermektedir.

Araştırmnın bir başka bulgusuna göre hem öğretmenler, hem veliler hem de çocukların öğrenme motivasyonu sağladığını düşündükleri, istek ve ihtiyaçların karşılanmasına yönelik duygusal ve sosyal faktörler üzerinde yoğunlaşmış oldukları görülmektedir. Ancak bu ihtiyaçların daha çok maddesel (teknolojik 
araçlar vb.) oluşu velinin bunları karşılama ihtiyacı dikkati çekmektedir. Kültürler ve bireyler değer öncelikleri ile betimlenebilmektedir. İnsanların zaman içinde değişen ihtiyaçları değer önceliklerinde de değişikliklere neden olabilmektedir (Kuşdil ve Kağıtçıbaşı, 2000). İletişim ve bilgi teknolojisinde yaşanan hızlı değişim ve gelişimlere toplumların yaşam tarzlarında değişiklikler yaratmış ve insanların artan şekilde teknolojiye daha fazla bağımlı olması ve hemen her şeyi sanal ortamda. (bilgisayar ortamında/internette, reklamlarda, filmlerde ya da dizilerde) yaşamasına yol açmıştır. Bu durum da bireylerin kimliklerini, dahası tüketim tercihlerini ve tüketici olarak davranışlarını da değişime uğratmış, davranış örüntüsü haline gelen yeni bir tüketim kültürünü ortaya çıkarmıştır (Nar,2015). Yaratılan büyülü imajlar, postmodern toplumlarda birey için tüketimi en önemli amaç haline getirmiştir (Slater, 1997'den akt: Hayta,2014). Yaşamını mutluluk eksenininde yürüten insanı gerçek anlamda neyin mutlu ettiğine yönelik sorgulamalar ise mutluluk-ihtiyaç ilişkisini ortaya koymuştur. Postmodern olarak nitelendirilebilen bu dönemde bireylerin mutluluk arayışı tüketime yönelmiş, tüketim anlayışı da bireylerin sembolik ihtiyaçlarının arttığı, zorunlu ve öncelikli ihtiyaçlarının tatmininin önemsizleştiği (Odabaşı, 2006) tüketicilerin tercih ettikleri ürün ve hizmetlerin sürdürülen yaşam tarzının kanıtı ve sosyal sınıfın göstergesi (Hayta,2014) olarak görüldüğü bir sürece dönüşmüştür. Çalışma grubundaki çocukların bir kısmının teknolojik aynı zamanda da pahalı araçlara sahip olmalarını sağlayabilen ailelerinin kendileriyle ilgilendiğini ifade etmeleri hem tüketim ihtiyaçları hem de var olmak istedikleri sosyal sınıfın bir göstergesi olarak görmeleri ile ilişkilendirilebilir. Ayrıca eğitim ve sosyo-ekonomik seviyeleri düşük olan ailelerin, hem teknolojik araçların öğrenmeyi daha kolaylaştırdığına yönelik yanlış inançları hem de kendi çocuklarının ekonomik durumu daha iyi olan ailelerin çocuklarından geri kalmalarını istememeleri ile birlikte çocuklarıyla geçirebilecekleri zamanı çalışarak geçirmek zorunda kalmaları nedeniyle kazançları çok az olmasına rağmen bu maddesel ve aynı zamanda pahalı araçları almaya yönelik çabalarını "çocuklarıyla ilgilenme" ilişkilendirmiş olabilecekleri söylenebilir. Bu algılarında çocuklarının tüketim kültürünün etkisiyle ilgilenme kavramını maddi özellikle de teknolojik ödüllerle ilişkilendirir hale gelmiş olmalarının da etkisinin olduğu da söylenebilir, çünkü aileler kendi yaşayamadıklarını çocuklarına yaşatmak istememekte onları mutlu etmeye çalışmaktadırlar.Ancak öğreneni merkeze almak ve onunla ilgilenmek yalnızca çocuklarının sınırsız isteklerini yerine getirmek, onlara sınırsız özgürlük tanımak değildir. Öğreneni merkeze almak bilgi birikimi, öğrenme ihtiyacı belirlenerek duygusal ve sosyal ve fiziksel, ihtiyaçları da göz önünde bulundurularak bu özelliklere uygun öğrenme ortamları oluşturabilmektir. Bu nedenle öğrenen merkezli eğitim anlayışının gerçek anlamı ile eğitim ortamına taşınması gerekmektedir.

Sonuç olarak çalışma grubundan elde edilen bulgulara dayanarak öğretmen, veli ve çocuğun eğitimsel anlamda çocukla ilgilenmek kavramına ilişkin görüşlerinin yapılandırmacı öğrenme yaklaşımının öngörüleri ile çeliştiği ve ilgilenmek kavramını davranışçı kuramın öğretileri ile açıklamaya çalıştıkları söylenebilir. 


\section{1. Öneriler}

- Bir eğitim anlayışının etkiliği gerçek manada anlaşılması ve eğitim öğretim ortamına taşınması önemli görülmektedir. Yapılandırmacı öğrenme yaklaşımın etkiliği de ne kadar anlaşıldığı ve uygulamalara yansıtılabildiği ile ilişkilidir. Öğrenme-öğretme sürecinde çocukla ilgilenme çocuğu hem bireysel hem de sosyal çevresiyle birlikte tanıyarak ihtiyaçlarına uygun olarak eğitim faaliyetlerini şekillendirme ve çeşitlendirme işidir. Bu bağlamda öğretmenlerin öğreten rollerinden çıkıp rehber rolünü benimseyebilmeleri için yapılandırmacı öğrenme ortamlarının hazırlanması konusunda seminerler, çalıştaylar düzenlenebilir.

- $\quad$ Eğitim seviyeleri ve toplumdaki statüleri açısından sıkıntı duyan ailelerin çocuğun birey olarak toplumda var olabilmesinin yolunu çocuklarının sınırsız isteklerini ve ihtiyaçlarını karşılamakla mümkün olabileceğine ilişkin algıları ve bunu gerçekleştirmeye yönelik çabaları dikkat çekmektedir. Ancak bu süreçte anne baba rolleri ile çocuk rollerinin yer değiştirdiği ailelerin eğitimde çocuk merkezli bir eğitim anlayışı yerine çocuk odaklı bir yaklaşım sergiledikleri görülmektedir. Öğrenen merkezli eğitim anlayışının çocuk odaklı-çocuk erkil bir yaklaşım olmadığını anlatmak ve bu bağlamda ataerkil aileden çocuk-erkil aileye geçiş sürecinde anne-babaya düşen roller ve çocuğun rolleri konusunda aileleri bilinçlendirmek için Rehberlik ve Psikolojik danışmanlık ve psikoloji alanları işbirliği ile anne baba eğitimi temalı projeler yürütülebilir.

- Çocuğun beklentileri ve ilgi arayışları dikkate alınmalı, çocuğun aile ve öğretmenden beklentilerinin daha çok maddesel oluşu ve daha çok teknolojik araçlarla kurdukları bağın öğretimsel amaçlara dönüştürülebilmesi için aile-okul işbirliğini güçlendirecek sosyal ve eğitimsel aktivitelerin ders programlarında yer bulması önerilebilir. 


\section{KAYNAKLAR}

Açıkgöz, K. (2003). Aktif Öğrenme. İzmir: Eğitim Dünyası Yayınları.

Ağgül Yalçın ve Bayrakçeçen, S. (2010). 5E öğrenme modelinin öğretmen adaylarının asit-baz konusu başarılarına etkisi. Uluslararası Online Eğitim Bilimleri Dergisi. 2(2), 508-531.

Akpınar, E. ve Ergin, Ö. (2005). Yapılandırmacı kuramda fen öğretmeninin rolü. Ilköretim-Online. 4(2), 55-64.

Akyol, H. (2007). Vygotsky, Piaget ve yapılandırmacı okuma eğitimi. VI. Ulusal Sinıf Öğretmenliği Kongresi Bildiri Kitabı. Eskişehir.

Akyol, S. ve Fer, S. (2010). Sosyal yapılandırmacı öğrenme ortamı tasarımının öğrenenlerin akademik başarılarına ve öğrenmenin kalıcıllğına etkisi nedir? International Conference on New Trends in Education and their Implications.Antalya.

Arkün, S. ve Aşkar, P. (2010). Yapılandırmacı öğrenme ortamlarını değerlendirme ölçeğinin geliştirilmesi.Hacettepe Üniversitesi Eğitim Fakültesi Dergisi. $39,32-43$.

Arslan, M. (2010). Eğitimde Yapılandırmacı Yaklaşımlar. Ankara Üniversitesi Eğitim Bilimleri Fakültesi Dergisi.40(1), 41-61.

Arslan, S. ve Özpınar, İ. (2008).Öğretmen nitelikleri: İlköğretim programlarının beklentileri ve eğitim fakültelerinin kazandırdıkları. Necatibey Ĕgitim Fakültesi Elektronik Fen ve Matematik Ĕ̈itimi Dergisi. 2 (1),38-63.

Aygören, F. (2009). Yapılandırmacı ögrrenme ortamlarının sinıf öğretmenlerinin ve okul yöneticilerin görüşlerine göre değerlendirilmesi: Çine Örneği. Yayımlanmamış Yüksek Lisans Tezi. Adnan Menderes Üniversitesi Sosyal Bilimler Enstitüsü Eğitim Programları ve Öğretimi Anabilim Dalı. Aydın.

Copley, J. (1992). The integration of teacher education and technology: A constructivist model. In D. Carey., R. Carey., D. Willis and S. Willis (eds), Technology and Teacher Education .Charlottesville VA: AACE.

Çiftçi,S., Sünbül, A. M. ve Köksal, O. (2013). Sınıf öğretmenlerinin yapılandırmacı yaklaşıma göre düzenlenmiş mevcut programa ilişkin yaklaşımlarının ve uygulamalarının eğitim müfettişlerinin görüşlerine göre değerlendirilmesi. Mersin Üniversitesi Eğitim Fakültesi Dergisi.9 (1), 281295.

Demirel, Ö ve Kaya, Z. (2006). Eğitim bilimne giriş̧. İstanbul: PegemA Yayıncılık.

Demirel, Ö. (2008). Yapılandırmacı Ĕgitim. Eğitim ve Öğretimde Çağdaş Yaklaşımlar Sempozyumu. İstanbul: HarpAkademileri Basımevi.

Dündar, Ş. (2008). Illköğretim sosyal bilgiler dersi ögrenme ortamlarının yapılandırmacı özellikler açısından değerlendirilmesi. Yayınlanmamış Doktora Tezi, Marmara Üniversitesi Eğitim Bilimleri Enstitüsü.

Erdem, E.ve Demirel, Ö. (2002). Program geliştirmedeYapılandırmacılık yaklaşımı. Hacettepe Üniversitesi Eğitim Fakültesi Dergisi. 23, 81-87. 
Fer, S. (2009).Social constructivism and social constructivist curricula in Turkey for the needs of differences of young people: Overview in light of the PROMISE project. In T. Tajmel\&S. Klaus (Eds.), Science education unlimited: Approaches to equal opportunity in learning science. Münster: Waxmann Verlag co. Publisher.

Fer, S.ve Cırık, İ. (2007). Yapılandırmacı öğrenme: Kuramdan uygulamaya. İstanbul: Morpa Kültür Yayınları.

Genç, S.Z. ve Eryaman, M. Y.(2008). Değişen değerler ve yeni eğitim paradigmas1. Sosyal Bilimler Dergisi. 9 (1), 89-102.

Güneş, F.(2014).Türkçe öğretiminde yaklaşım ve modeler. Ankara: Pegem A Yayınc1lik.

Han, Ç. (2013). Öğretmenlerin işlevsel paradigmaları ve eğitim reformu. Trakya Üniversitesi Eğitim Fakültesi Dergisi. 3,( 1), 59-79.

Hayta, A. B. (2014). Postmodern dönemin tüketim imajları: Postmodern tüketim kültürü, tüketim kalıpları ve postmodern tüketici. Hacettepe Üniversitesi Tüketici-Pazar-Araştırma-Danışma Test ve Eğitim Merkezi Tüketici yazlları (IV), 9-31.

Henson, K.T. (2003). Foundations for learner-centered educational: A knowledge base. Education 124 (1), 5-16.

Kabapınar, F. M., Sapmaz, N. A. ve B1kmaz, F. H. (2003). Aktif ögrenme ve ögretme yöntemleri, Fen bilgisi ögretimi. Ankara: Ankara Üniversitesi Eğitim Bilimleri Fakültesi Eğitim Araştırma ve Uygulama Merkezi (EAUM) Yayınları.

Karaçalı, A. (2004). Kerem Altun ile "öğretmen yeterlikleri" üzerine. Bilim ve Aklın Aydınlı̆̆ııda Ĕ̌itim Dergisi. 5(58).

Keenan, K. (1996). Motivation. Çev:Ergin KOPARAN. İstanbul: Remzi Kitabevi.

Köksal, O. (2014). 7E modeline göre düzenlenmiş öğretim etkinliklerinin 6. sınıf öğrencilerinin ingilizce dersindeki başarılarına, tutumlarına ve kalıcı öğrenmelerine olan etkisinin incelenmesi.Turkish Studies.9(5), 1459-1475.

Kuşdil, E. ve Kağıtçıbaşı, Ç. (2000). Türk öğretmenlerinin değer yönelimleri ve Scwartz değer kuramı. Türk Psikoloji Dergisi.15( 45), 59-76.

Meşe, C., Özer, S. ,Dindar, M.ve Odabaşı, H. F. (2014). İlgi ve BÖTE öğrencilerinin çalışma alanlarındaki önemi. Eğitimde Kuram ve Uygulama.10(1), 143-170.

Metin, M. ve Özmen H. (2009). Sınıf öğretmeni adaylarının yapılandırmacı kuramın 5e modeline uygun etkinlikler tasarlarken ve uygularken karşılaştıkları sorunlar. Necatibey Eğitim Fakültesi Elektronik Fen ve Matematik Eğitimi Dergisi. 3(2), 94-123.

Nar, M.Ş. (2015). Küreselleşmenin tüketim kültürü üzerindeki etkisi:Teknoloji tüketimi. Uluslararası Sosyal Araştırmalar Dergisi.8 (37), 941-954.

Ocak, G. (2012). Öğretmenlerin Yapılandırmacı öğrenme ortamı kurma başarılarının öğretmen ve öğretmen adaylarınca değerlendirilmesi. Eğitim ve Bilim. 37 (166), 25-40. 
Odabaşı, Y. (2006), Tüketim Kültürü-Yetinen Toplumdan Tüketen Topluma, 2. Baskı, İstanbul: Sistem Yayıncılık.

Özenç, M. ve Doğan C. (2007).Sınıf öğretmenlerinin yapılandırmacı yaklaşım yeterlik düzeylerinin belirlenmesi. Abant İzzet Baysal Üniversitesi Ĕgitim Fakültesi Dergisi. 12 (1), 67-83.

Özmen, H. (2004). Fen öğretiminde öğrenme teorileri ve teknoloji destekli yapılandırmacı öğrenme.The Turkish Online Journal of Educational Technology. 3(1), 100-111.

Özer, A. ve Kalaycı, I. (2012). Geleceğin yaratıcı çocuklarını yetiştirmek açısından eğitim sistemimiz ve Türkiye gerçeği. Uluslararası Katılımlı Çocuk Ihtiyaçları Sempozyumu. 18-19 Mayıs 2012.Ankara

Renninger, K.A.\&Hidi, S. (2002). Student interest and achievement: Developmental issues raised from a case study. In A. Wigfield and J.S. Eccles (Eds), Development of achievement motivation. (173-195). New York: Academic.

Renninger, K. A. (2000). Individual interest and its implications for understanding intrinsic motivation. In C. Sansone\&J. M. Harackiewicz (Eds.), Intrinsic and extrinsic motivation: The search for optimal motivation and performance. (373-404). San Diego, CA: Academic Press

Seven, M. A. ve Engin, A. O. (2008). Öğrenmeyi etkileyen faktörler. Atatürk Üniversitesi Sosyal Bilimler Enstitüsü Dergisi 12(2), 189-212.

Titiz,T. (2009). Ezbersiz eğitim: Yol haritası. İstanbul: Beyaz Yayınları

Topçu, İ. (2013). Okulu geliştirmede velilerin rolü (Sivas İl merkezinde bir durum çalışması). Yayımlanmamış doktora tezi. İnönü Üniversitesi Eğitim Bilimleri Enstitüsü Eğitim Bilimleri Ana Bilim Dalı Eğitim Yönetimi ve Denetimi Bilim Dalı. Malatya.

Yaşar, Ş., Gültekin, M., Türkan, B., Yıldız, N. ve Girmen, P. (2005). Yeni ilköğretim programlarının uygulamasına ilişkin sınıf öğretmenlerinin hazırbulunuşluk düzeylerinin ve eğitim gereksinimlerinin belirlenmesi. (Eskişehir Örneği). Yeni ilköğretim Programlarını Değerlendirme Seтроzуити. 14-16 Kasim 2005. Kayseri. 


\section{EXTENDED ABSTRACT}

From past to present, the question of how learners learn is a question that has been explained from various aspects. With the acceptance of the view that learning is an individual process, teacher centered approaches that regard students only as "recording devices" have been replaced by learner centered approaches in which learning environments are prepared according to student needs and interests and teachers are viewed as guides. Learner centered design places the child at the center by arranging teaching programs according to the child and by individualizing the task of learning (Güneş, 2014, Arslan and Özpınar, 2008).

One of the learner-centered approaches in recent years is constructivist learning approach that focuses on the constructing of the meaning by connecting learner's past knowledge and the new knowledge (Henson, 2003). According to this approach child constructs knowledge by utilizing prior knowledge and experiences and by making associations between new and prior information. These associations are influenced by many factors such as students' developmental characteristics, level of intelligence, fields, learning styles, creativity, attitudes and motivation levels, personal characteristics, interests, needs and habits. Therefore, constructivist approach attaches great significance to students' individual needs, strengths and weaknesses, interests and experiences (Çiftci, Sünbül and Köksal, 2013). Constructivist learning environment places more emphasis on how and why rather than what will be learned (Erdem and Demirel, 2002). Student achievement in terms of learning is related to efforts in the constructivist process by students as well as their parents, inner circle and teachers.

Constructivist approaches have been practised in Turkey starting with 2005-2006 academic year. According to the constructivist learning approach, learning can be explained by the adaptation of the internal and external factors affecting the individual.

Even if the curriculum is well prepared, the desired result can not be obtained in education-training if the teachers do not have the required qualifications (Yaşar et al., 2005; Demirel and Kaya, 2006, 337). However, changes in educational systems only signify the inception of the process and teachers are the ones who implement the programs in actuality. Teachers have significant roles and responsibilities to educate productive and progressive individuals who can criticize and challenge in line with the requirements of the modern age (Özenç and Doğan, 2007). As teachers families also have important duties and roles related to child's learning process. Teachers and families should cooperate to taking care of the child for effective learning.

\section{Purpose}

This study aimed to what the concept of taking care of the child, which can be regarded as a way to harmonize external factors with internal i.e. individual factors, means for teachers, parents and students. Answers to questions below were sought with this purpose:

- What does educational concept of "taking care of the child and taking the child as the center" mean for teachers? 
- What does educational concept of "taking care of the child and taking the child as the center" mean for parents?

- What does educational concept of "taking care of the child" mean for children?

In terms of the new roles defined by learner centered approach (constructivist learning approach).

\section{Method}

The study was undertaken as a descriptive study and research data were collected with collected with semi-structured interview questions and they were analyzed with descriptive content analysis.

\section{Study Group}

The study was conducted in the spring term of 2015-2016 academic year. A total of 150 individuals participated in the study: 50 classroom teachers, 50 students of these teachers and parents of these students (50).

\section{Result And Discussion}

As a result of rapid developments and transformations, societies today bear witness to various advances in social, political, cultural and economic aspects among others (Genç and Eryaman, 2008). These advances have resulted in changes in educational approaches as well by necessitating a learned centered educational approach. However adopting any educational approach is not enough by itself and students, teachers, social structure, parents and teachers should all renew themselves based on the adopted approach. Along with the new goal of "learning to learn" in educational environments, many things have undergone a transformation process such as learning approaches, learning-teaching process, evaluation and assessment, role of teachers, approaches to discipline, communication in the classroom, physical structure of classrooms and organization of the school. All these elements are holistically related. Change in one affects all others (Özer and Kalayc1, 2012). Changing educational trends of today expect teachers and parents to take the child to the center. In constructivist learning approach, taking care of the child means preparing learning environments based on student interest, needs and expectations and forming learning environments which facilitate learning.

The results of the current study show that the first expectation of teachers and parents from learning environments is academic achievement. However the factors that will lead to academic achievement are not mentioned. According to research findings, it can be argued that teachers, parents and students did not mention constructivist learning environments that can set into motion the internal factors and factors such as prior knowledge and learning needs that will affect knowledge structuring. Findings of the present study display that in academic terms, teachers, parents and children associated interest mostly with "teaching information". "Teaching information" is the vision of behavioral theory and it is contradictory with "knowledge structuring". Teachers, parents and children mentioned emotional and social factors that provide learning motivation to learn 
and concentrated on needs and ambitions. However, it is noteworthy that these needs are mostly material. Especially interest in expensive and technological tools by students and willingness and need to provide those by the parents is striking. Parents in the study may have explained the concept by their efforts to meet their technological needs in order to ensure their children are not left behind. These parents had lower socioeconomic statuses but they believed that technological tools facilitated learning and they wanted their children to keep up with the children with higher economic means. They also preferred these devices since they could not spend enough time with their children due to work and felt that meeting material and financial needs would be a sign of care and interest. It can also be argued that parents may have been affected by their children's associations between care and materialistic and especially technological rewards, therefore they strive to make their children happy by trying to meet the needs of their students in this area. However, taking the child to the center and caring for him in educational contexts do not mean to meet their unlimited desires and to provide them with unlimited freedom. Taking the learner to the center means providing learning environments by taking emotional, social and physical needs and by identifying learning needs. Learner centered educational approach should be practiced in educational environments. 